\title{
Epimycotic Algae on the Medicinal Fungus Trametes versicolor (L.) Lloyd
}

\author{
Pavel V. Videv ${ }^{1}$, Georg Gärtner², Blagoy A. Uzunov ${ }^{1}$, Petya H. Dimitrova ${ }^{1}$ \& Maya P. \\ Stoyneva-Gärtner ${ }^{1}$ \\ ${ }^{1}$ Sofia University “St K1. Ohridski”, Faculty of Biology, Department of Botany, 8 bld. \\ Dragan Zankov, Sofia, Bulgaria \\ ${ }^{2}$ University of Innsbruck, Institute of Botany, Sternwartestrasse 15, Innsbruck, Austria \\ Corresponding Author: Maya P. Stoyneva-Gärtner: mstoyneva@uni-sofia.bg
}

\begin{abstract}
The paper presents the species composition of algae, which develop on the surfaces of the medicinal fungus Trametes versicolor, collected in seven different sites of Bulgaria and investigated in cultures. All ten recorded epimycotic algae belong to the green evolutionary line (Chlorophyta -9 species and Streptophyta -1 species).The species composition on basidiomata collected from different sites was different with number of species varying from one to five. The same is valid for the species composition on different fungi from the same site. Therefore, we claim the lack of symbiotic relations between one specific alga and Trametes versicolor. Taking into account the ecological preferences of the recorded algae, it is possible to suppose with much higher probability that there is a relation between the epimycotic algae and nearest aerophytic phycoflora.
\end{abstract}

Keywords: aerophytic algae, aero-terrestrial algae, green algae, medicinal fungi, symbiosis

\section{INTRODUCTION}

The aero-terrestrial algae are important producers in land ecosystems but their taxonomy and biogeographic distribution have been scarcely studied at globe scale and in Bulgaria particularly [e.g. 1-3]. This is especially valid for the aerophytic algae which develop on the surface of the fungal fruiting bodies. Long they were commonly named as epiphytic and only recently the use of term epimycotic was advocated [4]. The only actual study on these algae in Bulgaria concerns their development on the surface of the basidiomycete Fomes fomentarius (L. ex Fr.). Kickx, on which four green aerophytic algae have been identified [4].

The development of algae on $F$. fomentarius is rare, while the presence of clearly visible algal growth on the surface of the fruiting bodies (basidiocarps, basidiomata) is typical for another basidiomycetous species with a tube-like hymenophore - Trametes versicolor (L.) Lloyd (Syn. Coriolus versicolor (L.) Quél.; Polyporus versicolor (L.) Fr.), most popular as Turkey tail. Four species from the green algal genera Chlorococcum Meneghini, Hormidium Kützing, Stichococcus Nägeli and Trebouxia Puymaly were documented from its surface in North America with the suggestion that the basidiocarps have the potential to be lichenized $[5,6]$.

The Turkey tail acguires high popularity due to its medical use in treatment of cancer (in particular the breast-cancer) and different infections [7, 8]. The study of the biodiversity of epimycotic species on its surface could help to clarify the nature of algal-fungal relationsand to provide ideas on the potential relation between them and the medical importance of the fungus. Therefore, the present paper is aimed on the species compostion of the epimycotic algae on T. versicolor based on cultural studies of field material collected from seven different sites of Bulgaria (Eastern Europe) and its comparison with the results of $[5,6]$ from North America.

\section{Material AND Methods}

The samples were collected by picking off the basidiocarps from their typical substrata - tree trunks or stems (Fig. 1) from seven sites: 1 - South Park of Sofia (42.6691N;23.3075E); 2 - Stara planina Mts, Villa zone nearby of Trudovets village (42.9333N; 23.8449E); 3 - Stara planina Mts, locality 
Pavel V. Videv et al.

Dzhendema (42.6584N; 24.9265E); 4 - Stara planina Mts, locality Dzhendema (42.6943N; 24.9513E); 5 - Vitosha Mt, vicinity of Boyana village (42.6386N;23.2640E); 6 - Vitosha Mt, vicinity of Zheleznitsa village (42.5348N; 23.3385E); - Vitosha Mt, vicinity of Simeonovo village(42.6081 $\mathrm{N} ; 23.3308 \mathrm{E}$ ). Sites 1-2 were situated in a large central park of the Bulgarian capital and in a small village garden, respectively, while sites 3-7 were from the natural deciduous forests. Six different fruiting bodies closely attached on two broken stemsofcherry trees in the same house garden of site 2 (Fig.1e) were sampled especially for comparison of the species composition of the epimycotic algae.

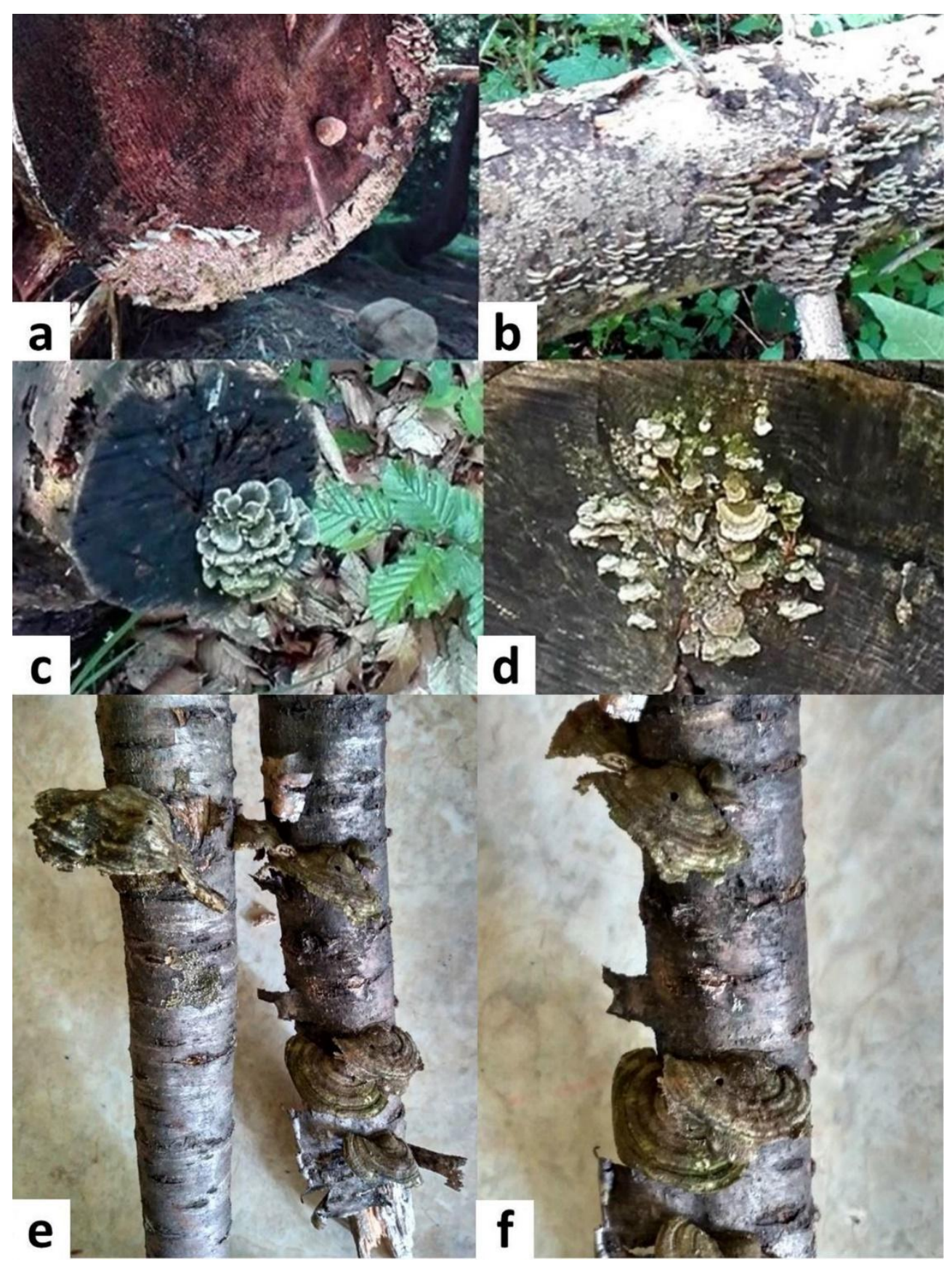

Fig1a-f. Basidiocarps of Trametes versicolor: a, b-from the vicinity of Simeonovo village on Vitosha Mt; c, d from the region Dzhendema in Stara planina Mts; e, $\mathrm{f}$ - from the vicinity of village Trudovets on Stara planina Mts. 


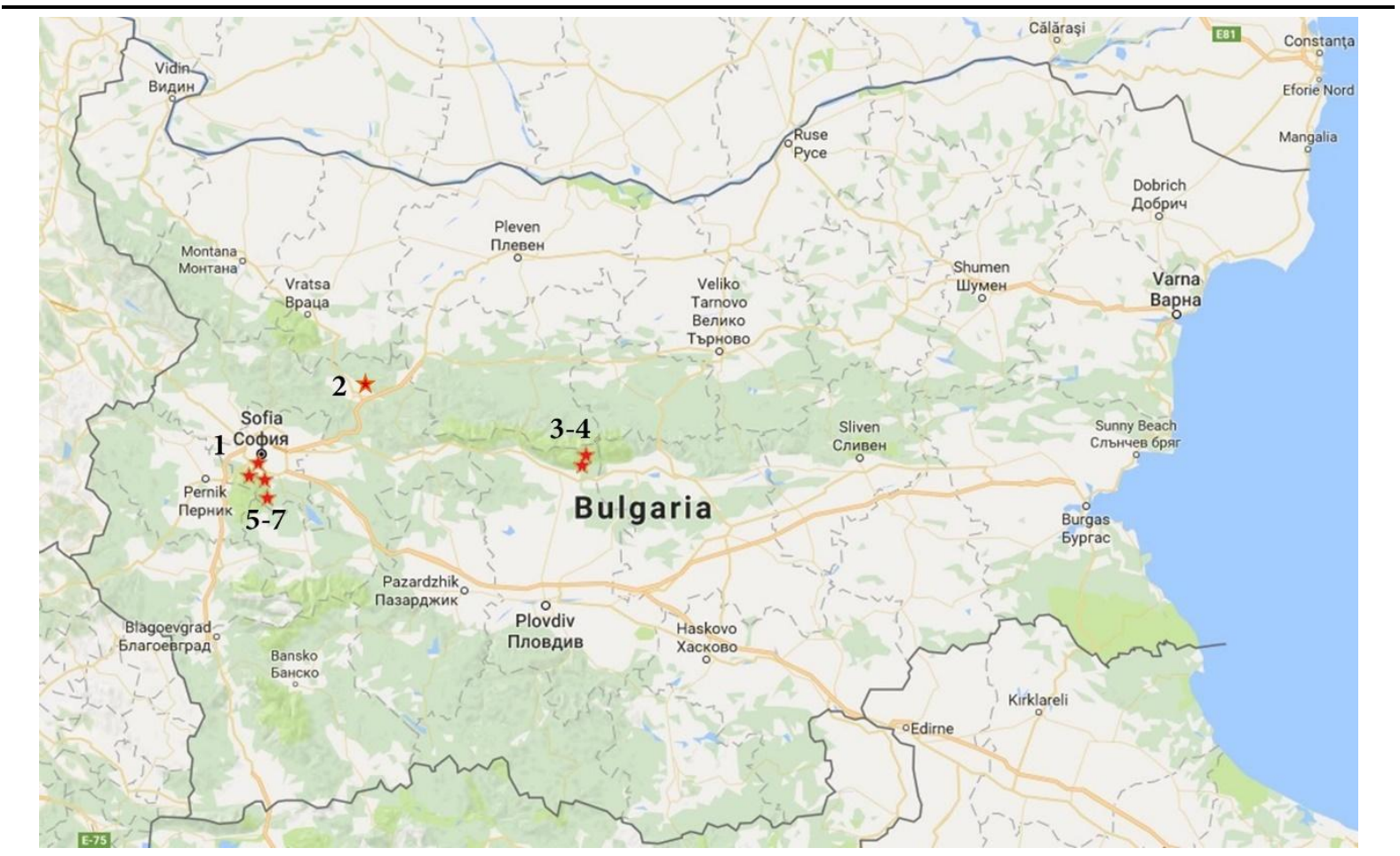

Figure2. Map of Bulgaria with location of the sampling sites.

After taking off from the substratum, the basidiocarps were kept in a paper envelope. In less than 24 hours they were transported to the laboratory in the Faculty of Biology of Sofia University "St. Kliment Ohridski” for further processing.

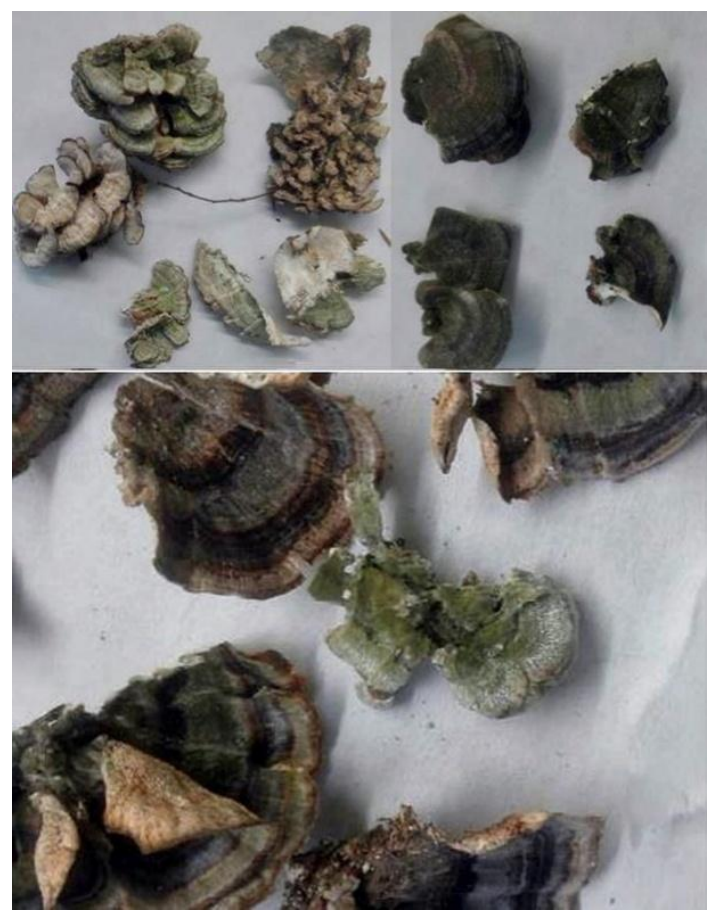

Figure3. Basidioacarps of Trametes versicolor prepared for further laboratory processing.

The cultivation and isolation of monocultures was done in the Algal collection of Sofia University ACUS [9] in Petri dishes with agar with Bold's Basal Medium (BBM) according to standard methods and techniques [10-14]. The material from all basiomata was scrapped out from the visible green layers of their upper surface on the agar (Fig. 4), and, in addition, pieces from the fruiting bodies were dragged on the agar surface with the green layers turned to the medium (Fig. 5). 
Pavel V. Videv et al.

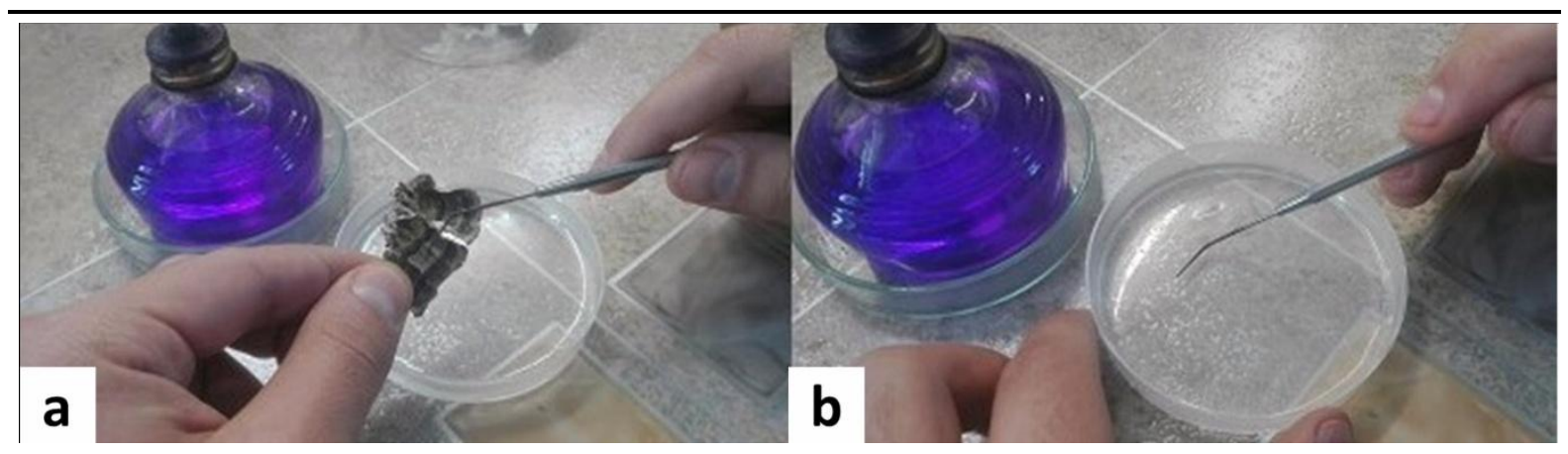

Figure 4a-b. Scratching of the material from the basidiocarp (a) and spread out of the material on the surface of the solid medium $(b)$.

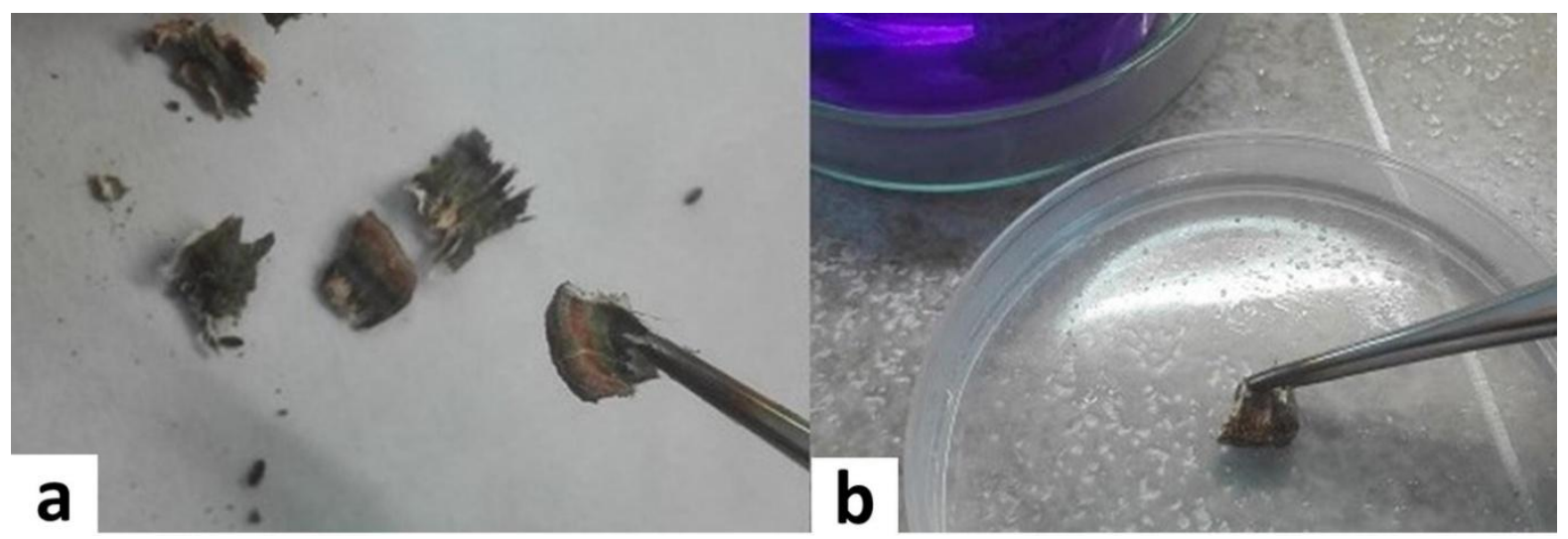

Figure 5a-b. Separation of small pieces of the basidiocarps (a) and dragging of the material on the surface of the solid medium $(b)$.

Another cultivation procedure was conducted in order to obtain algal cells free from fungal hyphae. Then the green layers were scratched out in the eprouvettes with liquid media. Afterwards the liquor was shaked and drops of the material were spread on the agar with BBM (Fig. 6).

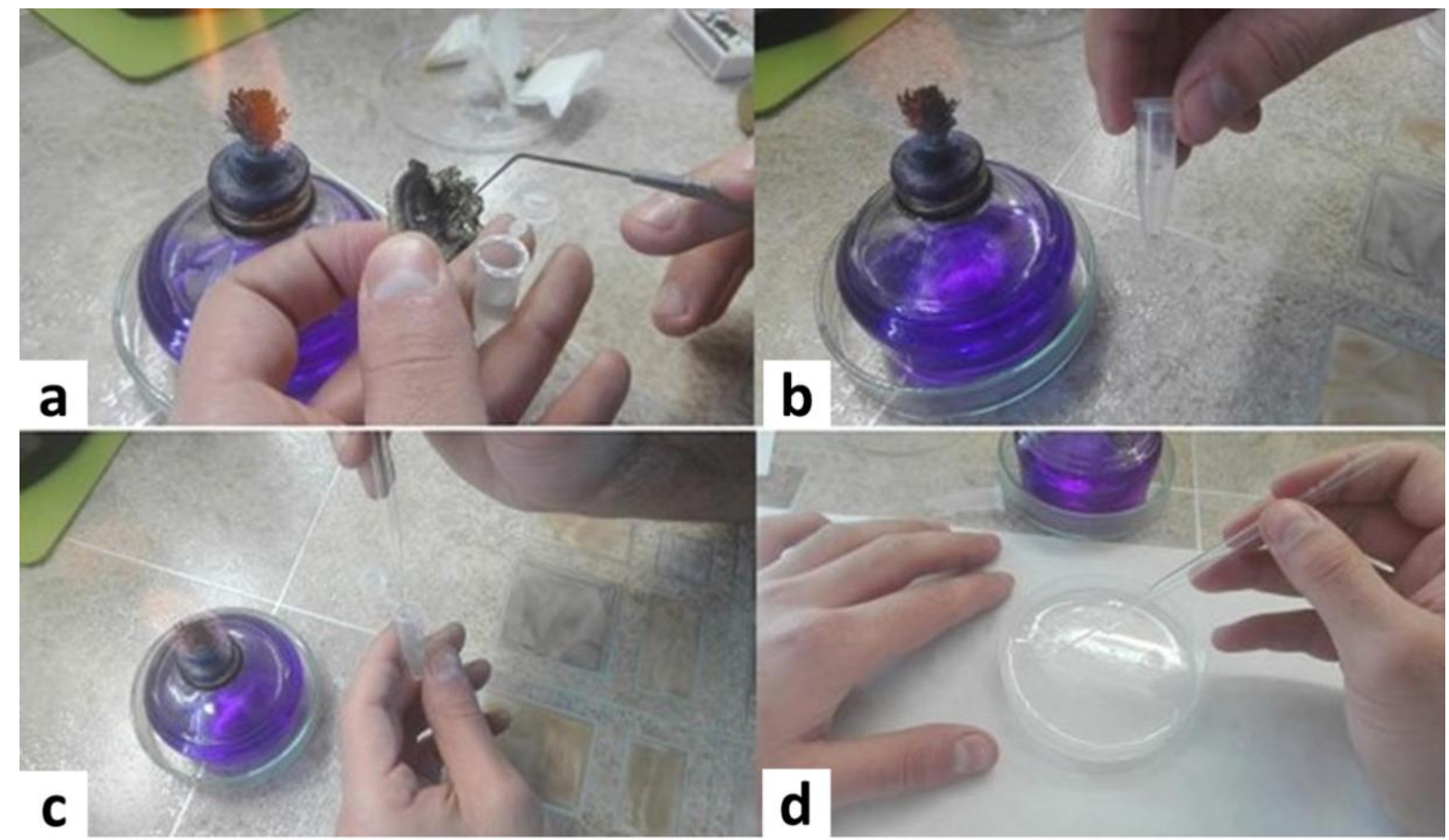

Figure 6a-d. Scrapping of the material in a liquid medium (a-b) and application of the drops with the algal material on Petri dishes with a solid medium $(c-d)$.

For obtaining of single colonies the material from Petri dishes was inoculated in new dishes with agar medium (Fig. 7). 
a

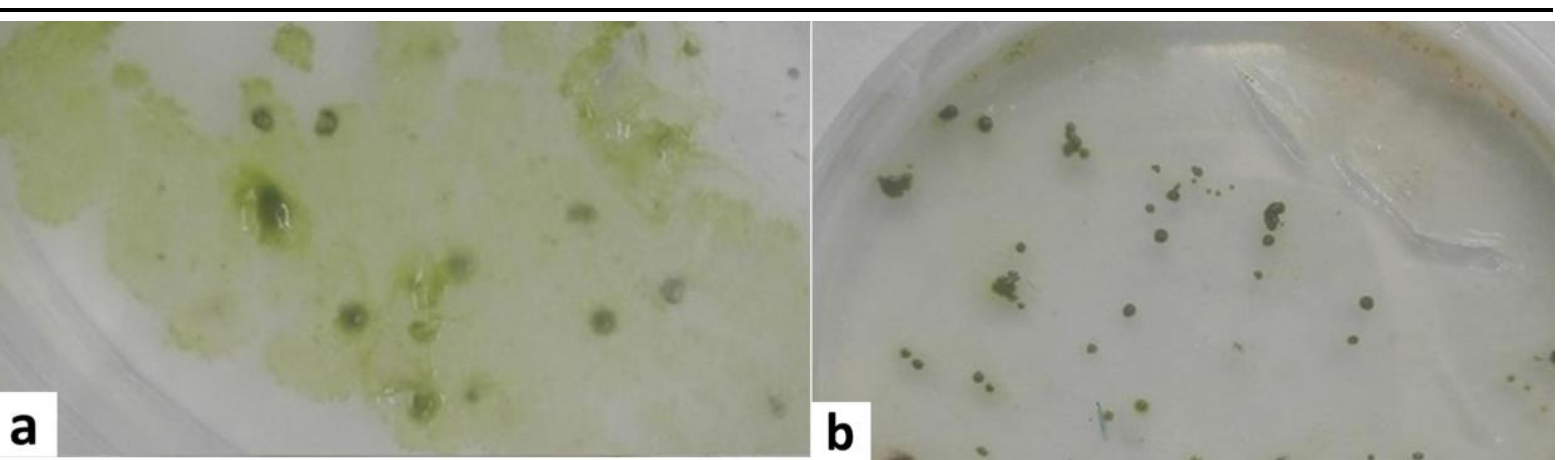

Fig.7a-b. Obtaining of algal colonies-mixed ( $a$ ) and singular (b).

The microscopic observations on the colonies were made on Motic binocular stereoscope with magnification 10x and 30x. Species identification was done on non-permanent microscopic slides on light microscope Motic BA 400 with an immersion objective. Standard staining of cell elements follows [15]. Microphotographs were taken by Moticam 2000 digital camera and were processed by the Motic Images Plus 2.0 program.

The identification of algae was done on the basis of standard taxonomic literature [16-36] and the taxonomy was consulted with AlgaeBase [37], following the International Code for Nomenclature of Algae, Fungi and Plants [38].

\section{RESULTS AND DISCUSSION}

In total 10 algal species were identified. All of them were green algae from the divisions Chlorophyta (9) and Streptophyta (1):

\section{CHLOROPHYTA}

Apatococcus lobatus (Chodat) J. B. Petersen: Distribution: Site 2.

Chlamydomonas moewusii Gerloff (Fig. 8): Distribution: Site 6.

Chlorella vulgaris Beijerinck (Fig. 8): Distribution: Sites 4, 5, 6.

Chlorella minutissima Fott et Nováková (Fig. 8): Distribution: Sites 1, 3, 4, 6.

Coccomyxa confluens (Kützing) Fott (Fig. 8): Distribution: Sites 3, 4, 6, 7.

Desmococcus olivaceus (Persoon ex Acharius) J. R. Laundon: Distribution: Site 2.

Sphaerocystis sp. (Fig. 8): Cells are spherical to elongated (before division), 9-10 $\mu \mathrm{m}$ long and 5-6 $\mu \mathrm{m}$ wide, covered with a mucilage sheath. The chloroplast is singular, parietal and slightly lobed and bears a pyrenoid with attached starch grains. The species identification was impossible because of lack of sporangia and zoospores in the materials. Distribution: Site 7.

Trebouxia cf. aggregata (Archibald) Gärtner (Fig.8): Distribution: Sites 2, 4.

Stichococcus bacillaris Nägeli (Fig. 8): Distribution: Site 7.

\section{STREPTOPHYTA}

Klebsormidium dissectum (F. Gay) H. Ettl et Gärtner: Distribution: Site 2.

The species found to develop epimycotically on $T$. versicolor are well-known representatives of the aerophytic algae $[12,13]$, most of which have been recorded on different substrata in Bulgaria [2-4, 39-41]. The algal distribution on basidiomata was different - in site 1 only Chlorella minutissima was detected, in site 5 - only Chlorella vulgaris, whereas in the other localities two to four species developed together on the fungal surface. Some of them were common for both mountain regions of Vitosha and Stara planina (Chlorella minutissima, Chlorella vulgaris and Coccomyxa confluens). By contrast, Apatococcus lobatus, Desmococcus olivaceus, Trebouxia cf. aggregata and Klebsormidium dissectum were recorded only in the samples from Stara planina Mts, and Chlamydomonas moewusii, Stichococcus bacillaris and Sphaerocystis sp. were found only in the samples from Vitosha Mt. 

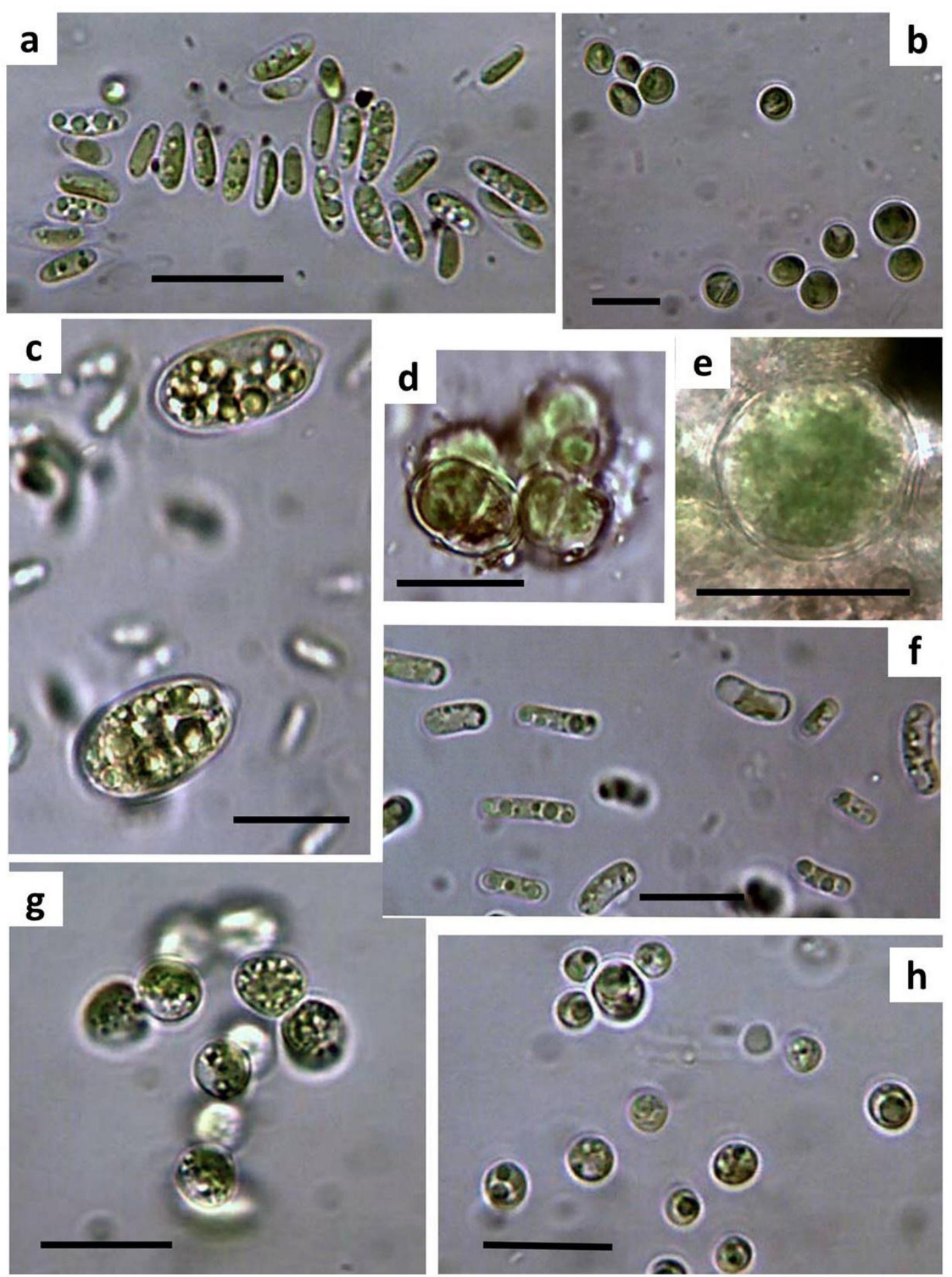

Fig. 8. Epimycotic species on Trametes versicolor: a - Coccomyxa confluens (Kützing) Fott, 2 - Chlorella vulgaris Beijerinck; c - Chlamydomonas moewusii Gerloff; d - Desmococcus olivaceus(Persoon ex Acharius) J. R. Laundon; e - Trebouxia cf. aggregata (Archibald) Gärtner; f - Stichococcus bacillaris Nägeli; g Sphaerocystis sp.; h - Chlorella minutissima Fott et Nováková. Scale bar $-10 \mu \mathrm{m}$.

The comparison beween the species composition on six different basidiomata from the region of Trudovets on Stara planina Mts (site 2) shows that Desmococcus olivaceus developed on all of them, but in various combinations with Apatococcus lobatus, Coccomyxa confluens, Klebsormidium dissectum and Trebouxia cf. aggregata.

\section{CONClusion}

Ten green algal species were recorded on the surface of $T$. versicolor, most of which have been documented also from the surfaces of other basidiomycetes (for details see [4]). This species composition is almost twice richer when compared with the four species published earlier for the 
surface of T. versicolor from North America [5, 6]. The common result from both studies is that all algae which develop epimycotically belong to the green evolutionary line and two genera coincide: Stichococcus and Trebouxia.

The detected difference in the species composition at the sites with different location and at different basidiomata from the same site clearly shows the lack of symbiotic relations between one specific alga and T. versicolor. Taking into account the statement of [6] that the occurrence of algae on this fungus is common, but not universal and the ecological preferences of the recorded algae, it is possible to suppose with much higher probability a relation between the epimycotic algae and the nearest aerophytic phycoflora. Doubtless, further studies with more data on epimycotes of $T$. versicolor from different sites with comparisons with their nearest aerophytes (on the tree barks, rocks or stone surfaces, soils, etc.) will provide more knowledge on the algal distribution on fungal surfaces.

\section{REFERENCES}

[1] Nienow J. A., Ecology of subaerial algae, Nova Hedwigia. 112, 537-552 (1996).

[2] Uzunov B. A., Stoyneva M. P. and Gärtner G., Review of the studies on aero-terrestrial cyanoprokaryotes and algae in Bulgaria with a Checklist of recorded species. I, Phytologia Balcanica. 13(1), 65-73 (2007).

[3] Uzunov B. A., Stoyneva M. P. and Gärtner G., Review of the studies on aero-terrestrial cyanoprokaryotes and algae in Bulgaria with a Checklist of recorded species. II., Phytologia Balcanica. 14(1), 11-18 (2008).

[4] Stoyneva M. P., Uzunov B. A. and Gärtner G., Aerophytic green algae, epimycotic on Fomesfomentarius (L. ex Fr.) Kickx, Annual of Sofia University “St. Kliment Ohridski”, Faculty of Biology, Book 2 - Botany 99, 19-25 (2015).

[5] Zavada M. S. \&Simoes P., The possible demi-lichenization of the basidiocarps of Trametes versicolor (L.: Fries) Pilat (Polyporaceae), Northeastern Naturalist. 8(1), 101-112 (2001).

[6] Zavada M. S., DiMichele L. and Toth Ch. R., The demi-lichenization of Trametes versicolor (L.: Fries) Pilat (Polyporaceae): The transfer of fixed $\mathrm{CO} 2$ from epiphytic algae to T. versicolor, Northeastern Naturalist. 11 (1), 33-40 (2004).

[7] Chu K. K. W., Ho S. S. S. and Chow A. H. L., Coriolus versicolor: A medicinal mushroom with promising immunotherapeutic values, The Journal of Clinical Pharmacology. 42, 976-984 (2002).

[8] Standish L. J., Wenner C. A., Sweet E. S., Bridge C., Nelson A., Martzen, M. and Torkelson, C., Trametes versicolor Mushroom Immune Therapy in Breast Cancer, Journal of the Society for Integrative Oncology. 6(3), 122-128 (2008).

[9] Uzunov B., Stoyneva M., Mancheva A. and Gärtner G., ACUS - the new collection of living aeroterrestrial algae of the University of Sofia "St Kliment Ohridski", Proc. VII Natl. Conf. Bot., 29-30.09.2011, Sofia, Pp. 271-274 (2012)

[10] Pringsheim E. G., Pure cultures of algae, their preparation and maintenance, Cambridge University Press, 119 (1946).

[11] Andersen R. (ed.), Algal culturing techniques, Elsevier Academic Press, Phycological Society of America, 578 (2005).

[12] Ettl H. and Gärtner G., Syllabus der Boden-, Luft- und Flechtenalgen, Gustav Fischer Verlag, Stuttgart, Jena, New York, 721 (1995).

[13] Ettl H. and Gärtner G., Syllabus der Boden-, Luft- und Flechtenalgen, Spektrum, New York, 773 (2014).

[14] Gärtner G., Stoyneva M. P., Mancheva A. D. and Uzunov B. A., A New Method in Collection and Cultivation of Aerophytic and Endolithic Algae, Ber. nat. med. Verein Innsbruck, 96. 27-34 (2010).

[15] Ettl H. and Gärtner G., Chlorophyta II. Tetrasporales, Chlorococcales, Gloeodendrales, Verlag, New York, 436 (1988).

[16] Bourrelly P., Les Algues d'eau douce. Initiation à la systématique, Tome I: Les Algues Vertes, Société nouvelle des editionsboubéé 9, Paris $\left(6^{\mathrm{e}}\right), 572$ (1990).

[17] Ettl H., Chlorophyta I: Phytomonadina, VEB. G. Fischer Verlag, Jena, 807 (1983). 
[18] B. Fott and M. Nováková, A monograph of the genus Chlorella. The freshwater species, Praha, Academia, pp. 10-59 (1969)

[19] Gärtner G. and Ettl H., Neugliederung der Gattung Chlorococcum Meneghini (Chlorophyta, Chlamydophyceae, Chlorococcales), Nova Hedwigia. 47(3-4), 271-278 (1988).

[20] Gärtner G. Die Gattung Trebouxia Puymaly (Chlorellales, Chlorophyceae). Algological Studies. 41, 495-548 (1985)

[21] Hindák F., Key to the unbranched filamentous green algae (Ulotrichiniae, Ulotrichales, Chlorophyceae), Bull. Slov. bot. spoločnosti SAV. Suppl. (1), 1-77 (1996).

[22] Hindák F. (ed.), Sladkovodnériasy, Bratislava, Slovensképedagogickénakladatelśtvo, 724 (1978).

[23] Hindák F., Komárek J., Marvan P. and Ruzicka J., Kluc na urcovanie vytrusnych rastlin, I diel. Riasy. Bratislava, SPN, 398 (1973).

[24] Ikeda T. and Takeda H., Species-specific differences of pyrenoids in Chlorella (Chlorophyta), Journal of Phycology. 31, 813-823 (1995).

[25] D. M. John, Orders Chaetophorales, Klebsormidiales, Microsporales, Ulotrichales, The Freshwater Algal Flora of the British Isles. An Identification Guide to Freshwater and Terrestrial Algae, Cambridge University Press, pp. 433-486 (2002).

[26] D. M. John and F. Rindi, Filamentous (nonconjugating) and plantlike green algae, Freshwater Algae of North America. Ecology and Classification. Elsevier, pp. 375-428 (2015).

[27] D. M. John and P. M. Tsarenko, Order Chlorococcales, The Freshwater Algal Flora of the British Isles. An Identification Guide to Freshwater and Terrestrial Algae. Cambridge University Press, pp. 327-409 (2002).

[28] Kessler E., Chlorella. Biochemische Taxonomie einer für Forschung und Biotechnologie wichtigen Gattung einzelliger Grünalgen, Naturwissenschaften. 79, 260-265 (1992).

[29] Kessler E. and Huss V. A. R., Comparative physiology and biochemistry and taxonomic assignment of the Chlorella (Chlorophyceae) strains of the Culture Collection of the University of Texas at Austin, Journal of Phycology. 28, 550-553 (1992).

[30] Komárek J. and Fott B., Das Phytoplankton des Süßwassers, Systematik und Biologie, Stuttgart, 1044 (1983).

[31] Pliński M. and Hindák F., Zielenice - Chlorophyta. Green algae (with the English key for the identification of the genus), Gdańsk,WUG, 239 (2010).

[32] Shubert E. and G. Gärtner, Nonmotile Coccoid and Colonial Green Algae, Freshwater Algae of North America. Ecology and Classification. Elsevier, pp. 315-374 (2015).

[33] Starmach K., Chlorophyta III. Zielenice Nitkowate: Ulothrichales, Ulvales, Prasiolales, Sphaeropleales, Cladophorales, Chaetophorales, Trentepohliales, Siphonales, Dichotomosiphonales (with keys for the identification of filamentous green algae mentioned in this volume), Warszawa-Kraków, PWN, 750 (1972).

[34] Škaloud P., Variation and taxonomic significance of some morphological features in European strains of Klebsormidium (Klebsormidiophyceae, Streptophyta), Nova Hedwigia. 83(3-4), 533550 (2006).

[35] E. Tschermak-Woess, The algal partner, CRC Handbook of Lichenology. Volume 1, CRC Press, Boca Raton, Florida, 1989, pp. 39-92.

[36] Uzunov B.A., Gärtner G. and Stoyneva M.P., Notes on the akinete-forming strain of the green alga Klebsormidium dissectum (Streptophyta) from Pirin Mts., Bulgaria, Phyton - Annales Rei Botanicae. 52 (1), 139-144 (2012).

[37] Guiry M. D. and Guiry G. M., AlgaeBase. World-wide electronic publication, National University of Ireland, Galway, http://www.algaebase.org (2017).

[38] McNeil J., Barrie F. R., Buck W. R., Demoulin V., Greuter W., Hawksworth D. L., Herendeen P. S., Knapp S., Marhold K., Prado J., Prud'homme van Reine W. F., Smith G. F., Wiersma J. F. and Turland J. F. (eds.), International Code of Nomenclature for algae, fungi and plants (Melbourne Code): Adopted by the Eighteenth International Botanical Congress Melbourne, Australia, July 2011. Regnum Vegetabile 154. Königstein: Koeltz Scientific Books, 208 (2012). 
[39] Gärtner G. and M. P. Stoyneva, First study of Aerophytic Cryptogams on Monuments in Bulgaria, Ber. nat.-med. Verein Innsbruck. 90, 73-82 (2003).

[40] Stoyneva M. P. and G. Gärtner G., Remarkable and newly recorded aeroterrestric cyanoprokaryotes and algae in Bulgaria, Proceedings of IV Balkan Botanical Congres, Sofia 2026 June 2006, Pp. 122-127 (2009).

[41] Stoyneva M., Mancheva A., Gärtner G.and Uzunov B., Are the algae from the uncommon Belogradchik rocks common ones?, Proc. VII Natl. Conf. Bot., 29-30.09.2011, Sofia, Pp. 265269 (2012). 